\title{
Study on Employment Psychology of Students in Southwest Petroleum University
}

\author{
Yong Jiang1, Min Zhou ${ }^{2}$ \\ ${ }^{1}$ College of Chemistry and Chemical Engineering, Southwest Petroleum University, Chengdu, China \\ ${ }^{2}$ College of Food Science, Sichuan Agricultural University, Ya'an, China \\ Email: jiangyong1990@163.com
}

How to cite this paper: Jiang, Y., \& Zhou, M. (2019). Study on Employment Psychology of Students in Southwest Petroleum University. Creative Education, 10, 1108-1115. https://doi.org/10.4236/ce.2019.106083

Received: May 7, 2019

Accepted: June 15, 2019

Published: June 18, 2019

Copyright (c) 2019 by author(s) and Scientific Research Publishing Inc. This work is licensed under the Creative Commons Attribution International License (CC BY 4.0).

http://creativecommons.org/licenses/by/4.0/

\section{(c) (†) Open Access}

\begin{abstract}
In recent years, the employment situation of students in Southwest Petroleum University has become increasingly serious. How to integrate ideological and political education into the employment of college students and play an important role in the employment of college students is an important issue for ideological and political educators. This paper is based on the investigation and research of the students of Southwest Petroleum University, and makes a comparative study of the employment psychology of the students of corresponding majors, so as to put forward effective adjustment strategies, aiming at alleviating the psychological burden of the employment of contemporary college students. Firstly, the paper elaborates the employment status of students at Southwest Petroleum University, especially in different majors; secondly, through comparative study, it points out the different employment psychology of students at Southwest Petroleum University; finally, through in-depth study, it formulates targeted and effective adjustment strategies for the different employment psychological problems of students.
\end{abstract}

\section{Keywords}

Employment Situation, Ideological Education, Employment Psychology, Adjustment Strategy, Southwest Petroleum University

\section{Introduction}

Since 1999, Chinese colleges and universities have expanded their enrollment substantially year after year. In 1999, the enrollment of general colleges increased from 1.596 million to 2.261 million in 2000 and from 2.6828 million in 2001. In 2005, 4.75 million students were enrolled in the National College Entrance Examination. In 2008, 5.99 million students were enrolled in the National 
College Entrance Examination (Albrecht, 2008). In just ten years, the number of students enrolled in Colleges and universities has nearly quadrupled. Undoubtedly, the expansion of enrollment has indeed improved the overall quality of the people and enabled more young people of school age to enjoy education (Creswell \& Plano Clark, 2007). However, due to the lack of hardware and software resources in some universities, the quality of college students has declined dramatically, and there are many people who haven't learned knowledge in four years, which has led to many people unable to find jobs in the increasingly incentive employment competition. Expansion of enrollment has also led to a decline in the treatment of college students (Dammert, 2009). In many areas, the treatment of college graduates is not as good as that of front-line workers. Many universities are forced by the pressure of low employment rate, and the phenomenon of employment rate fraud appears. The difficulty of college students' employment has become an important problem in the whole society (Dawid, Ludescher, \& Trukeschitz, 2008).

Southwest Petroleum University is the second undergraduate petroleum university founded in New China. It is a co-established university with the central and local governments and is mainly managed by the Sichuan Provincial People's Government. In 2013, the school was selected as one of the 100 universities in the "Basic Capacity Building Project of Universities in the Midwest of China". In September 2017, it was selected as the first batch of "double first-class" world-class discipline construction universities in China. With the expansion of enrollment in the country, the students of Southwest Petroleum University are also expanding sharply. In today's increasingly severe employment situation in the social environment, especially in the current oil economic downturn, the employment situation deteriorated (Dawid, Ludescher, \& Trukeschitz, 2008), and some college students will inevitably deviate from the track of job hunting psychology, even in a confused state. Therefore, timely detection and correction of these psychological errors, and effective guidance, can successfully meet the employment challenges, and ultimately achieve full employment of college students (Fleischer, 2010).

\section{Common Unhealthy Psychology of College Students in Choosing Careers}

Through investigation and research, the common bad psychology of students at Southwest Petroleum University in choosing jobs is as follows:

1) Acute Success and Instant Benefit

This is the most common and unavoidable unhealthy psychology of college students when choosing a job (Flick, 2007). It refers to the psychological tendency of college students in choosing jobs blindly pursuing those jobs with rich income and high social prestige and yearning for economically developed areas with superior living environment. This psychological tendency of college students in choosing jobs has also been confirmed by many surveys on college stu- 
dents' behavior in choosing jobs in recent years. The survey shows that the nature of the units chosen by college students is foreign-funded enterprises, joint ventures, institutions, state-owned enterprises and party and government organs in turn; the areas where college students choose units are Shanghai, Beijing, Shenzhen, Guangzhou, Suzhou, Hangzhou and Dalian in turn. Firstly, these preferred places for college students are limited, which cannot meet the general requirements of college students. Secondly, their own conditions are different. These are professions that college students generally yearn for, not necessarily the best choice for their own career.

2) Dependence Psychology

Some graduates have received four years of University education, but they lack the experience of job hunting and career selection, and even lack the ability of analysis and decision-making to solve problems that a graduate should have. For example, in choosing a job, whether a unit is suitable for oneself is often decided not by one's own thinking, but by listening to the opinions of parents, teachers, siblings and classmates, showing a strong psychological dependence. For fresh university graduates who depend on psychology, they should be trained to make specific analysis according to the specific situation, and then make choices. They should be taught the ways and methods of judging and making decisions, so that they can mature as soon as possible (Frate, 2014).

3) Emotional Fluctuation

In the process of choosing a job, college students are prone to abnormal fluctuations in their emotions, which are mainly manifested in negative emotional states such as anxiety, anxiety and even depression. A survey of college students' pre-career emotional state shows that depression and anxiety prevail in college students before job-hunting, and the anxiety level of female students is higher than that of male students, while the depression level is lower than that of male students (Gerlach \& Laß, 2012). The main reasons for college students' emotional fluctuation and abnormality before choosing a job include: severe employment situation, college students' lack of self-confidence and sufficient ability to withstand pressure, love distress, family background and so on.

4) Blind Comparison

College students do not fully consider their own actual situation, such as their professional scope, professional interest and career pursuit, practical ability and comprehensive quality, blindly conform to the masses and tend to be new in the process of choosing jobs (Haberkern, 2009). In this psychology, even if a unit is very suitable for its own development, but because there are some differences in some aspects than their expectations, they choose to give up, but regret afterwards. Some graduates lack overall consideration, do not suit their own abilities and interests of career pursuit, often suffer unnecessary setbacks in choosing a career, delay or lose employment opportunities.

5) Blind Pursuit of Heights

Some college students unilaterally consider their ideal of job-hunting and em- 
ployment, as long as all aspects of the employer are perfect, from wages and welfare benefits, housing, geographical location to working environment are all in their consideration, but ignore whether such a perfect unit can accept itself (Ivancevich, 2007). This kind of blind pursuit of high expectations without considering their talents and learning, and without giving them a reasonable position, is the psychological incentive for many college students to "fail high, fail low" in choosing jobs. This kind of mentality makes many college students often miss out with the employers who are very suitable for them.

6) Unbalanced Psychology

Because of the lack of comprehensive quality and ability, or because of the lack of social background, or because of the inaccurate opportunity, some college students cannot find ideal work units. However, these college students are often incorrect attribution, complaining, resulting in unbalanced psychology. This unbalanced mentality often leads to a few college graduates' biased views on society and life. Therefore, schools and teachers should pay attention to strengthening their timely and effective guidance (Jabsen \& Blossfeld, 2008).

7) Inferiority Complex

In the fiercely competitive job market, some college students often have a strong sense of inferiority because of the depression of their major, or because their professional knowledge, professional skills and comprehensive quality are inferior to other students, or because of repeated setbacks in job hunting, which often leads to a strong sense of inferiority, and then transforms into inferiority psychology. College students with this kind of psychology often have no confidence and courage to face the employer, cannot properly show their strengths to the employer, and even turn their strengths into weaknesses, thus seriously affecting employment and career choice.

8) Conceit

Contrary to inferiority complex, some college graduates are extremely conceited because their major is very popular, or because they study in a famous university, or because they are superior in both professional study and comprehensive quality, or because they are favored by many employers because of their excellent conditions. However, in the deep of their hearts, they are extremely arrogant and superior. Under such psychological control, it is often "this mountain looks at that mountain". This unit is not pleasant, and that unit is not satisfactory, resulting in the loss of arms with many employing units suitable for their own development. For the excellent university graduates with self-confidence, we should guide them to identify themselves and recognize their own shortcomings.

\section{The Psychological Barriers of College Students in Choosing Careers}

1) Anxiety

This is caused by psychological conflicts or setbacks, mainly fears, uneasiness, 
anxiety and so on. On the eve of graduation, most college students' psychological problems are characterized by excessive anxiety. In particular, some college students from remote areas, or introverted personality, or physical defects, or poor academic performance, as well as female college students, are more prominent. This anxiety makes them nervous and nervous when choosing a job.

2) Inferiority Complex

Lack of self-esteem, self-confidence, lack of correct self-awareness, self-shame, lack of confidence and courage. This makes some college students pessimistic about employment, while hindering the normal play of their intelligence and creativity. Excessive inferiority will lead to mental depression, negative world weariness and even extreme.

3) Cowardice

This is a timid and fragile personality trait. For example, when participating in an employer's interview, they often blush, incoherent, incoherent answers to questions, and forget all the "lines" they prepared before the interview; or because they are cautious, they are afraid that a wrong word or a bad answer to a question will affect their image in the employer's eyes, dare not speak freely, and fail to show their own characteristics and advantages (Kittl, 2003).

4) Pride

Loneliness and arrogance are the manifestations of the lack of objective self-analysis and self-evaluation. When choosing a job, they tend to be ambitious, expecting too much, easily divorced from reality, replacing reality with fantasy, which makes a great contrast between the goal and reality of choosing a job.

5) Indifference

This is a negative psychological response to setbacks. When choosing a job, some college students feel powerless and lose confidence because of setbacks. They often have the mentality of not thinking of enterprising, low mood, indifference and numbness of will. This mentality is not compatible with the competitive mechanism and social environment of employment (Kofahl, Arlt, \& Mnich, 2007).

\section{The Main Adjustment Strategies of Employment Psychological Problems}

1) Effective guidance and help for the change of college students' professional roles

Guiding college students to plan their career reasonably. Many students do not have the consciousness of changing their professional roles before they go to work. This requires the employment instructors in Colleges and universities to organize and plan in advance to promote students' professional consciousness, and to conduct systematic and targeted guidance and guidance:

a) Psychological tests are conducted on college students to understand their career orientation, and to orientate their career perception. On the other hand, 
we should strengthen the guidance training of Vocational awareness, and help students to train their vocational skills by combining the teaching of school professional courses and simulated practice.

b) Guiding students to recognize themselves, understand themselves, understand their strengths and strengths, so as to stimulate students' career motivation and interest, so as to locate their career orientation accurately, constantly cultivate and improve their professional role awareness, reduce blindness in job hunting, and improve the success rate.

c) Implementing the whole-process service of employment guidance to enable students to understand the relationship between study and employment as soon as possible. At the same time, schools should strengthen contacts and communication with enterprises, actively explore the employment market, enrich students' employment channels, and provide more opportunities for students to work and practice, which will be conducive to the consolidation of students' professional role consciousness.

2) Cultivating and Exercising College Students' Related Abilities Other than Intellectual Factors

In the fierce market competition, whether enterprises or individuals can cooperate together is an important criterion to test whether they can succeed in an invincible position. Under our traditional educational background and system, we have always emphasized students' ability to complete independently and competitively, as well as their sense of competition. Therefore, it is particularly important to train and train college students' basic psychological quality and improve their comprehensive ability (Kreimer, Meier, \& Straußlberger, 2010).

3) Strengthen mental health education for College Students

In any situation, psychological endurance is very important. If the psychological endurance of college students is not strong, they cannot be treated rationally and cope freely when they are confused in job hunting. Therefore, strengthening college students' mental health education is a strong foundation and guarantee for them to enter the society and work.

4) College students should know themselves objectively and improve their knowledge structure

In the face of various contradictions and problems in the process of job hunting, college students should first correctly understand and evaluate themselves ideologically and correctly understand their interests. Secondly, understand your temperament type correctly. Different temperament types are suitable for different career directions. Generally speaking, people's personality characteristics can be divided into four types: polyhemia, mucus, bile and depression. According to the classification of temperament types and the different characteristics of their performance, graduates should examine themselves and choose their own occupation. Finally, we should correctly recognize our strengths and strengths. Perspective oneself, fully perceive one's own strengths, let one's potential play out, and be able to skillfully use in practical operation. 


\section{Conclusion}

Job hunting is a realistic problem that college students must face. The quality of college students' job hunting psychology is closely related to the success of job hunting. At present, the employment situation of students in Southwest Petroleum University is becoming more and more serious, and many graduates are at a loss under the influence of the traditional concept of career choice, resulting in many psychological misunderstandings and emotions in the process of job hunting, as well as complex psychological forms such as inferiority, confusion, helplessness, burnout, feeling unfair, and envying others. Students' employment psychology is becoming more and more contradictory. Through researching the corresponding countermeasures, making college students keep a good and healthy Job-hunting Psychology is not only conducive to increasing their job-hunting weight under the severe employment situation, but also conducive to college students' taking fewer detours in the long road of job-hunting and career-hunting.

\section{Conflicts of Interest}

The authors declare no conflicts of interest regarding the publication of this paper.

\section{References}

Albrecht, S. (2008). Burnout-The Path to Be Followed. Burnout in the Light of Theory and Practice. Saarbrücken: VDMVerlag.

Creswell, J. W., \& Plano Clark, V. L. (2007). Designing and Conducting Mixed Methods Research. Thousand Oaks, CA: Sage.

Dammert, M. (2009). Relatives in the Focus of Carepolicy: How Sustainable Is the Subsidiary Logic of German Care Insurance. Wiesbaden: VS Verlag für Sozialwissenschaften. https://doi.org/10.1007/978-3-531-91535-7

Dawid, E., Ludescher, M., \& Trukeschitz, B. (2008). Careby Relatives-Results and Conclusions from the European Study Eurofamcare. Informationsdienst Altersfragen, 3, 9-14.

Dawid, E., Ludescher, M., \& Trukeschitz, B. (2008). What Do You Want to Do More than More Flexible Working Hours, Teleworking, Permanent Leave...? A Qualitative Study of Nursing-Friendly Measures in Viennas Companies. (Forschungsbericht). Wien: Forschungsinstitutes für Altersokonomie.

Fleischer, E. (2010). Organisation of Care. In E. Appelt, M. Heidegger, M. Preglau, \& M. A. Wolf (Eds.), Who Cares? Betreuung und Pflege in Osterreich (pp. 177-186). Innsbruck: Studien Verlag.

Flick, U. (2007). Qualitative Social Research. Hamburg: Rowohlt Verlag.

Frate, N. (2014). The Compatibility of Informal Care and Employment at the Alpen-Adria University Klagenfurt. Unveroffentlichte Diplomarbeit, Klagenfurt: Alpen-Adria Universitat

Gerlach, I., \& Laß, I. (2012). Whole of Society Effects Operating Family Policy. In I. Gerlach, \& H. Schneider (Eds.), Betriebliche Familienpolitik. Kontexte, Messungen und Effekte (pp. 241-260). Wiesbaden: Springer VS Verlag für Sozialwissenschaften. 
https://doi.org/10.1007/978-3-531-93330-6_13

Haberkern, K. (2009). Care in Europe: Family and the Welfare State. Wiesbaden: VS Verlag für Sozialwissenschaften. https://doi.org/10.1007/978-3-531-91617-0

Ivancevich, J. M. (2007). Human Resource Management (11th ed.). New York: McGraw-Hill Irwin.

Jabsen, A., \& Blossfeld, H. P. (2008). The Impact of Home Care on Work Sharing in the Family. Zeitschrift für Familienforschung, 3, 293-321.

Kittl, H. (2003). Environment and Quality of Domestic Supply of Elderly under Socio-Educational Perspective. Unveroffentlichte Dissertation, Graz: Universitat Graz, Institut für Erziehungsund Bildungswissenschaft.

Kofahl, C., Arlt, S., \& Mnich, E. (2007). “In Good and in Bad Times.”-On the Differences and Similarities of Caring Spouses and Other Caregivers in the German Part of the Study Project EUROFAMCARE. Zeitschriftfür Gerontopsychologie \& Psychiatrie, 20, 211-225. https://doi.org/10.1024/1011-6877.20.4.211

Kreimer, M., Meier, I., \& Straußlberger, M. (2010). The Compatibility of Family Care for the Elderly with Employment in the Context of the Austrian Care Policy.

http://static.uni-graz.at/fileadmin/Unikid-Unicare/2010_Kreimer-Meier_Vereinbarkeit -familiaerer-Altenbetreuung-mit-Erwerbsarbeit_Kurzfassung.pdf 